\title{
PENGOLAHAN KOTORAN SAPI \\ DENGAN TEKNOLOGI BIOGAS REAKTOR KECIL
}

\section{PROCESSING COW FECES \\ WITH BIOGAS REACTOR TECHNOLOGY SMALL}

\author{
Hermain Teguh Prayitno \\ Kantor Penelitian dan Pengembangan Kabupaten Pati \\ Email : hermain_prayitno@yahoo.com
}

Naskah Masuk : 26 September 2014 Naskah Revisi : 10 Oktober 2014 Naskah Diterima : 16 Oktober 2014

\begin{abstract}
Research on alternative energy and fertilizer has been done and applied, but the public not interest yet to make this alternative energy and fertilizer. This is due to the huge costs, the process is complicated, and low economic value. Biogas processing, liquid fertilizers and solid. If the large volume of water mix will increase the volume of the reactor and the implications for the huge cost. The research objective was to determine variations in the sample which is capable of representing the processing of the biogas process and product stability. The method used in laboratory scale experiments and determination of the best results using factor analysts. The results of the research is reactor $B$ and $A$ that can be used as a reference treatment that produces biogas manure optimal, and the volume of 0.56 liters of biogas per one kilogram of cow dung with a processing time of 38 days.
\end{abstract}

Keyword : biogas, mixture, small reactor

\begin{abstract}
ABSTRAK
Penelitian mengenai energi dan pupuk alternatif sudah banyak dilakukan dan diterapkan, akan tetapi minat masyarakat untuk membuat energi dan pupuk alternatif ini belum ada. Hal ini disebabkan oleh biaya yang besar, prosesnya yang rumit, dan nilai ekonominya rendah. Pengolahan biogas, pupuk cair dan padat. Jika dengan volume campuran air yang besar akan membesarkan volume reaktor dan berimplikasi pada besarnya biaya. Tujuan penelitian adalah untuk mengetahui variasi sampel mana yang mampu mewakili proses pengolahan dengan kesetabilan proses dan produk biogas. Metode yang digunakan percobaan skala laboratorium dan penentuan hasil terbaik menggunakan analis faktor. Hasil penelitian yaitu reaktor B dan A yang dapat digunakan sebagai acuan pengolahan kotoran sapi yang menghasilkan biogas optimal, dan volumenya 0,56 liter biogas setiap satu kilogram kotoran sapi dengan waktu pengolahan 38 hari.
\end{abstract}

Kata kunci : Biogas, campuran, reaktor kecil 


\section{PENDAHULUAN}

Kebijakan subsidi yang dilakukan pemerintah selalu menimbulkan pendapat pro dan kontra. Ada kalangan yang berpendapat bahwa subsidi tersebut tidak sehat sehingga berapapun besarnya, subsidi harus dihapuskan dari APBN, (Munawar, 2013). Sementara pihak lain berpendapat bahwa subsidi masih diperlukan untuk mengatasi masalah kegagalan pasar. Pelaksanaan subsidi memerlukan pengubahan pola subsidi yang sesuai dengan kondisi. Misalkan, pengalihan subsidi secara bertahap dari subsidi harga yang kurang efektif dan tidak tepat sasaran kepada subsidi bahanbahan kebutuhan pokok bagi masyarakat kurang mampu (targeted subsidy). Kebijakan subsidi non-energi supaya lebih fokus kepada program subsidi untuk mengurangi beban masyarakat miskin, dan membantu usaha kelompok kecil dan menengah. Misalkan lebih fokus kepada subsidi pupuk atau subsidi benih. Apabila pemerintah akan menerapkan kebijakan pengurangan subsidi secara bertahap, maka harus dipilih terlebih dahulu skenario yang berdampak paling kecil serta berdasarkan database kependudukan yang akurat, (Munawar, 2013)

Keberpihakan

pemerintah, menipisnya sumberdaya mineral dan energi global, serta kemampuan menurunkan daya dukung lingkungan akibat energi fosil mengharuskan pemerintah dan masyarakat mulai mengembangkan energi alternatif ramah lingkungan. Menurut Wahyudi (2013), strategi pengembangan biogas dapat dilakukan dengan penambahan biogas dengan skema pembiayaan swadaya masyarakat, lembaga donor, dan pemerintah. Hal ini menggambarkan bahwa pengadaan bangunan biogas belum mampu dilakukan oleh peternak sendiri dalam hal biaya.

Demikian juga menurut Prayitno (2014), strategi pemanfaatan kotoran sapi yaitu nilai faktor internal sebesar 2,38 pada posisi pertumbuhan melalui integrasi horisontal dan faktor eksternal nilainya 2,81 pada posisi stabilitas. Strategi ini menjadi strategi pertumbuhan integrasi horisontal dengan cara memperluas kegiatan lini produk atau membangun ditempat lain dengan tujuan meningkatkan jenis produk dan jasa. Kesimpulan strategi jangka pendek dengan menggiatkan peternak kecil tersebar di seluruh kabupaten Pati untuk pemanfaatan kotoran sapi menjadi energi dan pupuk alternatif untuk kebutuhannya sendiri, dan memberi bimbingan dan dukungan menjadi lebih mandiri menuju jangka panjang. Sedangkan strategi jangka panjang adalah inovasi terusmenerus guna kesempurnaan, kemudahan proses, dan peralatan yang murah sehingga dapat ditiru peternak kecil untuk menghadapi mahalnya harga LPG dan pupuk pasca pencabutan subsidi.

Upaya pemanfaatan kotoran sapi sebagai bahan biogas, pupuk cair dan pupuk padat telah banyak diteliti dan dikembangakan, akan tetapi masih bersifat substansi. Penelitian yang baik dan bukan yang terbaik, akan tetapi tidak menghasilkan sisa dan mampu mengangkat sisa tersebut menjadi produk lainnya. Hasil penelitian tersebut bersifat komprehensif dan bukan substantif, sebagai contoh hanya meneliti produktifitas biogas, kualitas pupuk cair dan padat. Padahal hal tersebut dapat dilakukan secara bersamaan dalam sebuah penelitian.

Permasalahan

dalam

pengembangan teknologi biogas disebabkan oleh besarnya biaya 
pengadaan reaktor karena volumenya yang besar. Volume dan ruang gas syarat dengan kebocoran, maka kualitas bangunan harus terjamin dan mahal. Jadi upaya mengecilkan volume dan memisahkan gas dari reaktor dengan menguji apakah proses metanansi dengan campuran air yang sedikit dapat terjadi.

Dengan demikian tujuan penelitian ini adalah untuk mengetahui variasi sampel mana yang mampu mewakili proses pengolahan dengan kesetabilan proses dan produk biogas.

\section{TINJAUAN PUSTAKA}

\section{Investasi Biogas}

Menurut Widodo dkk (2006), reaktor biogas dengan investasi $\mathrm{Rp}$ 18.448.000,- menghasilkan pendapatan Rp 600.000,- perbulan jika dikonversikan dengan harga LPG pada saat itu. Hal itu menjelaskan bahwa pendapatan pengolahan biogas sangatlah murah yaitu Rp 20.000,- perhari. Wajar sekali jika pendapat beberapa petani yang mengetahui kondisi tersebut berkomentar lebih baik dana investasi tersebut dibelikan sapi saja. Analisa kelayakan ekonomi menunjukkan investasi layak dengan B/C Rasio 1,35 dan modal kembali pada tahun ke-4 (umur ekonomi digester 20 tahun). Hasil pendapatan ini belum termasuk hasil samping berupa pupuk cair/padat.

Menurut Arifin dkk (2011) dalam kesimpulan menjelaskan bahwa penghematan yang diperoleh dari penggunaan seperangkat instalasi bioelektrik yang terdiri dari satu genset (daya maksimal 2,5 $\mathrm{kW}$ ) dan satu perangkat digester (kapasitas $7 \mathrm{~m}^{3}$ ) adalah sebesar Rp. 40.896/bulan.

\section{Komposisi Campuran dan Produktivitas Biogas}

Komposisi campuran $1: 1$ menggunakan kotoran sapi $200 \mathrm{Kg}$ feses dan 200 liter air dengan waktu 45 hari menghasilkan biogas sebesar 0,66 liter/Kg/hari (Widodo dkk, 2006). Perbandingan biogas dari bahan kotoran Kuda, sapi, dan kerbau campuran 1:1 yaitu $60 \mathrm{Kg}$ feses dan 60 liter air selama 31 hari menghasilkan biogas terbaik yaitu $0,31 \mathrm{l} / \mathrm{Kg} / \mathrm{hari}$. Kesimpulannya yaitu kotoran kuda lebih tinggi total biogasnya, disusul sapi dan kemudian kerbau. Sedangkan komposisi bahan isian sangat berpengaruh terhadap volume dan kualitas biogas yang dihasilkan (Mara dan Alit, 2011)

Perbandingan dari bahan kotoran sapi, kuda, dan campuran daun jati dengan campuran 2:3 waktu tinggal 40 hari, didapatkan produksi biogas tertinggi 0,18 liter/Kg bahan/hari dari campuran kotoran kuda dan $10 \%$ daun jati. (Widyasmara dkk, 2012)

Saputro dan Putri dalam Wati dkk (2014) menggunakan kotoran sapi, rumen, dan campuran air dengan perbandingan $1: 1,1: 2$, dan $1: 3$ selama 90 hari menghasilkan biogas yang tertinggi yaitu 0,38 liter/Kg/hari oleh bahan feses, rumen, dan air masing masing 1:1:1. Kesimpulannya yaitu semakin meningkatnya kadar air semakin meningkat produksi biogas yaitu 1:3. Demikian juga dengan semakin banyak penambahan rumen mampu meningkatkan produksi biogas tetapi hanya dua bagian dari feses saja.

Feses sapi dengan campuran 1:1 yaitu $3.500 \mathrm{Kg}$ feses dan 3.500 liter air dalam reaktor biogas selama 30 hari 
menghasilkan biogas $\quad 0,55 \quad$ liter $/ \mathrm{Kg}$ feses/hari. (Arifin dkk, 2011).

Menurut Sasongko (2010) kotoran sapi dengan campuran 1:3 mampu menghasilkan $\quad 0,2 \quad 1 / \mathrm{Kg} / \mathrm{hari}$ skala laboratorium, lebih tinggi dari skala pilot $0,18 \quad \mathrm{Kg} / \mathrm{hari}$ agitasi. Dengan kesimpulan sebagai berikut 1) hasil analisis multivariat skala laboratorium menunjukkan bahwa $\mathrm{P}$ kurang dari 0,05 , rasio pengenceran berpengaruh nyata terhadap perombakan substrat maupun produksi biogas, 2) produksi biogas paling banyak pada rasio pengenceran 1:3 dengan rerata 1,11 //hari. Rasio pengenceran $1: 1 ; 1: 5$ dan $1: 7$ rerata produksi biogas masing-masing 1,03 1/hari, 0,43 1/hari dan 0,37 1/hari. Selanjutnya direkomendasikan untuk skala semi pilot digunakan rasio pengenceran $1: 1$, dan rasio $1: 3$ dan $1: 3$ dengan agitasi, 3) agitasi berpengaruh nyata terhadap efisiensi perombakan bahan terlarut maupun produksi biogas. Rerata produksi biogas sebesar 18 $\mathrm{m} 3$ /hari untuk rasio pengenceran 1:3 dengan agitasi, $6,62 \mathrm{~m}^{3} /$ hari dengan perlakuan tanpa agitasi, dan hasil tersebut lebih tinggi dibanding rasio $1: 1=6,16$ $\mathrm{m}^{3} /$ hari.

\section{METODOLOGI PENELITIAN}

Lokasi penelitian di Desa Jatimulyo Kecamatan Wedarijaksa dengan Waktu Penelitian bulan juni sampai bulan Agustus 2014. Variabel penelitian dilakukan dengan memvariasi penambahan cairan slurry (stater) kembali ke dalam proses biogas dengan perbedaan volume disetiap reaktor sebagai berikut 1) reaktor A yaitu 7 liter berisi 6 liter campuran feses $3,5 \mathrm{Kg}$, stater 1 liter, dan air 1,5 liter; 2) reaktor B yaitu 7 liter berisi 6 liter campuran feses $3,5 \mathrm{Kg}$, stater 0,75 liter, dan air 1.75 liter; 3) reaktor $\mathrm{C}$ yaitu 7 liter berisi 6 liter campuran feses $3,5 \mathrm{Kg}$, stater 0,5 liter, dan air 2 liter; 4) reaktor D yaitu 7 liter berisi 6 liter campuran feses $3,5 \mathrm{Kg}$, stater 0,25 liter, dan air 2,25 liter.

Bahan menggunakan kotoran sapi brahman dengan pencampuran air dan peralatan skala laboratorium menggunakan peralon 4 inch dengan assesoris seperti terlihat dalam Gambar 1.

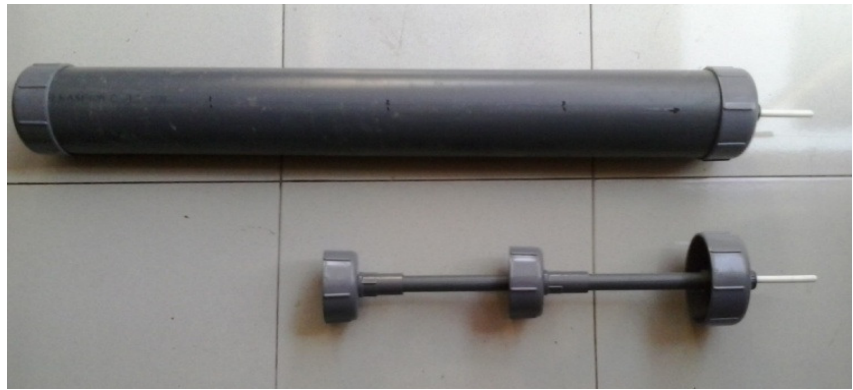

Gambar 1.

Foto reaktor biogas sekala laboratorium

Sumber : Dokumentasi Penelitian, 2014

Prosedur percobaan dilakukan dengan persiapan yaitu 1) pembuatan stater perbandingan 1: 1 selama 20 hari, 2) pembuatan reaktor penelitian skala laboratorium, 3) pengambilan bahan kotoran ternak sapi.
Pelaksanaan percobaan dengan urutan 1) pemasukan feses sapi $3,5 \mathrm{Kg}$ ditambah stater dengan variasi 0,$25 ; 0,5$; 0,$75 ; 1$ liter kemudian ditambah air hingga mencapai volume 6 liter, 2) pemasangan penahan feses di dalam 
reaktor dan menutupnya hingga rapat, 3 ) pemasangan selang gas disambungkan dengan botol mineral (penangkap gas), 4) pembacaan volume produksi biogas setiap hari selama 38 hari, 5) percobaan pembakaran biogas setiap hari, 6) pencatatan dalam tabel penelitian.
Data diambil dengan membaca volume produksi biogas reaktor a, b, c dan d setiap hari selama 38 hari dan diolah dengan grafik kurva normal. Analisis data dengan metode interdependen/analisis faktor (Ghozali, 2001).
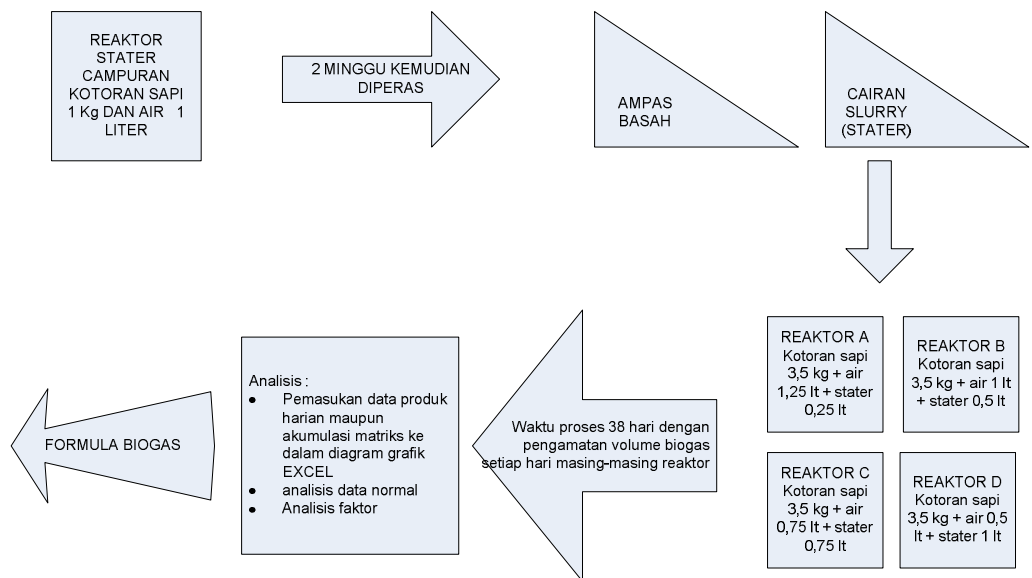

Gambar 2.

Diagram Alir Penelitian

\section{HASIL DAN PEMBAHASAN}

Ternak berlokasi rumah Bp Sahri Ds Jatimulyo RT 3 RW 1 Kecamatan Wedarijaksa Kabupaten Pati.
Jenis sapi Brahman, ukuran panjang badan $128 \mathrm{~cm}$ keliling dada 203 $\mathrm{cm}$ dan berat badan perkiraan 500-510 $\mathrm{kg}$, dan berat feses 3 waktu pengambilan rata-rata $15 \mathrm{Kg}$.

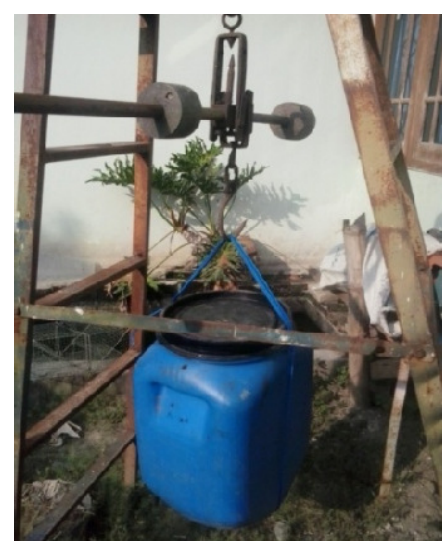

Gambar 3.

Foto penimbangan feses sapi brahman

Sumber : Dokumentasi Penelitian, 2014 
Bahan dicampur dengan air dan cairan slurry dimasukkan kedalam empat reaktor biogas kemudian disambungkan selang gas menuju botol bekas aqua 1,5 liter untuk pembacaan produksi gas setiap hari.

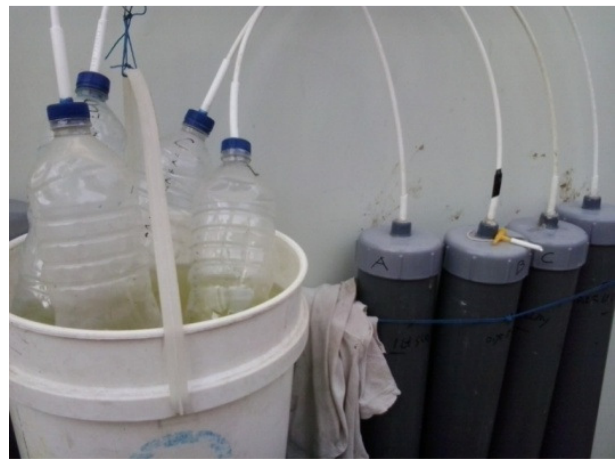

Gambar 4.

Foto reaktor dan wadah gas

Sumber : Dokumentasi Penelitian, 2014

Hasil pembacaan volume gas setiap hari selama 38 hari di sampaikan dalam bentuk grafik sperti disajikan pada Gambar 5.

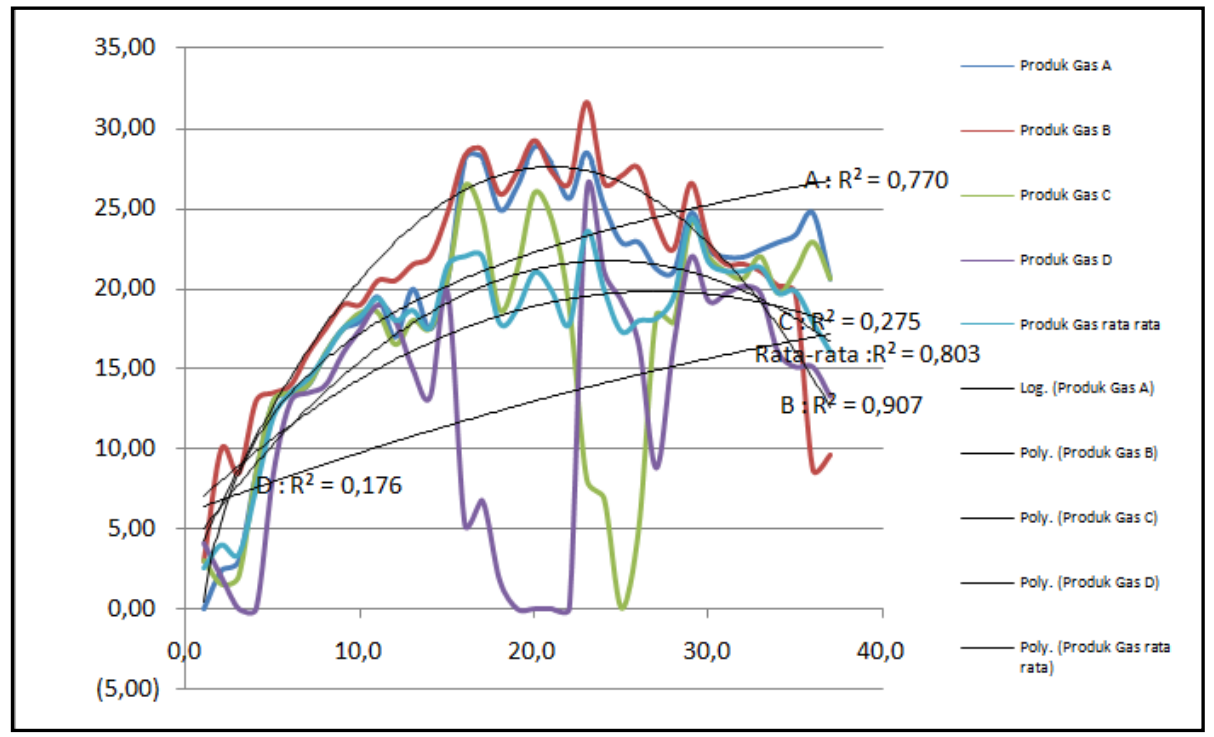

\section{Gambar 5.}

Grafik Volume Biogas Setiap Hari

Sumber : Pengolahan Data, 2014

Gambar 5 merupakan gambaran hasil volume biogas setiap hari dan ratarata selama 38 hari dari reaktor a sampai d. $\mathrm{R}^{2}$ menunjukkan hanya reaktor $\mathrm{b}$ yang produksi biogasnya melebihi produksi rata-rata $(0,803)$ yaitu 0,907 .
Akan tetapi gambaran tersebut belum dapat digunakan sebagai alat untuk mengambil keputusan. Maka pengujian $\mathrm{R}^{2}$ pada data akumulasi setiap hari selama 38 hari dalam grafik linier sebagaimana disajikan pada Gambar 6. 
Jurnal Litbang Vol. X, No. 2 Desember 2014: 123-132

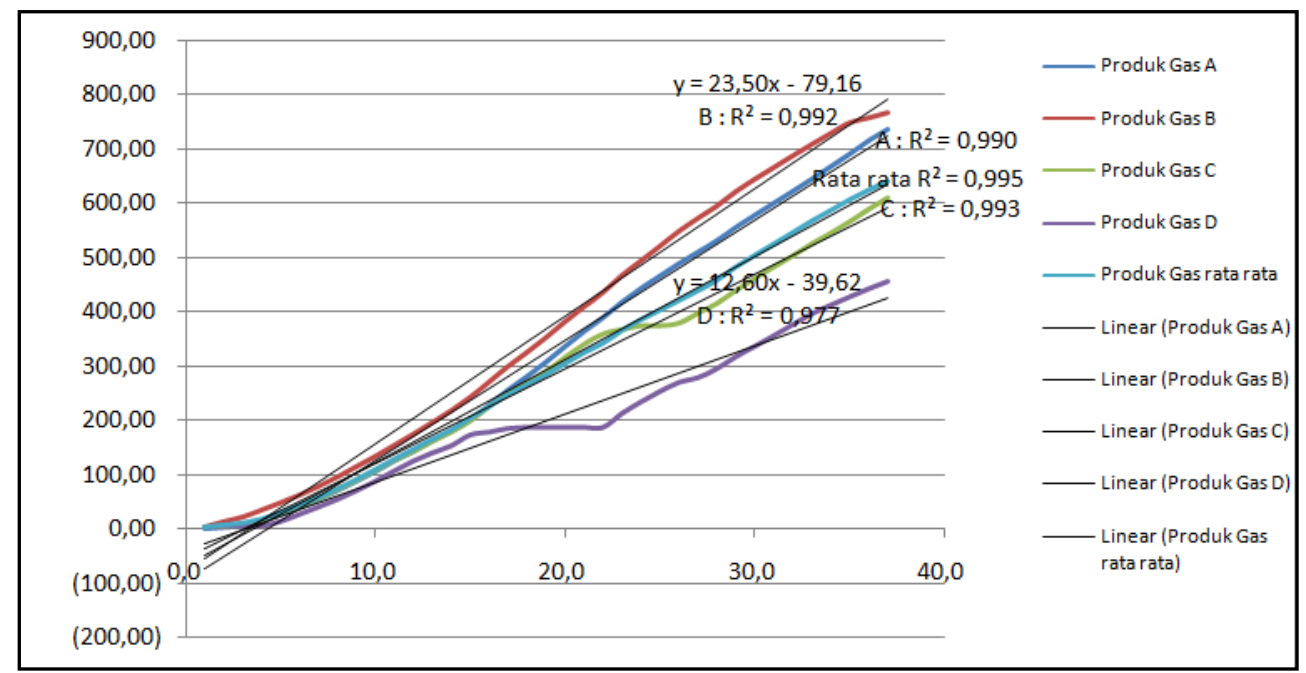

\section{Gambar 6.}

Grafik Volume Biogas Akumulasi

Sumber : Pengolahan Data, 2014

Grafik linieritas pada Gambar 6 menjelaskan bahwa hanya produk gas rata-rata yang tertinggi 0,995 disusul dengan reaktor B 0,992, A 0,990, C 0,993, dan D 0,977.

Untuk melakukan analisis statistik maka data harus dilakukan screening dengan asumsi bahwa penggunaan statistik parametrik adalah asumsi multivariate normality yaitu variabel dan semua kombinasi linier dari variabel berdistribusi normal. Normalitas data menggunakan uji Statistik KolmogorovSmirnov dengan hipotesis :

Hipotesis Nol (Ho) : data terdistribusi secara normal

Hipotesis Alternatif (HA) : data tidak terdistribusi secara normal.

Tabel 1.

One-Sample Kolmogorov-Smirnov Test

\begin{tabular}{|ll|r|r|r|r|}
\hline & & Produk Gas A & Produk Gas B & Produk Gas C & Produk Gas D \\
\hline N & & 38 & 38 & 38 & 38 \\
Normal Parameters & & & & \\
& Mean & 19.6289 & 19.8632 & 16.2632 & 12.1921 \\
& Std. Deviation & 6.96667 & 7.39866 & 7.06741 & 7.5685 \\
Most Extreme Differences & Absolute & .179 & .164 & .199 & .200 \\
& Positive & .115 & .083 & .084 & .121 \\
& Negative & -.179 & -.164 & -.199 & -.200 \\
& & 1.104 & 1.012 & 1.229 & 1.235 \\
Kolmogorov-SmirnovZ & & .174 & .258 & .097 & .095 \\
\hline Asymp. Sig. (2-tailed) & & & & &
\end{tabular}

a. Test distribution is Normal.

Sumber : Pengolahan Data, 2014

Hasil uji Kolmogorov-Smirnov (K-S) untuk variabel produk gas A, B, C, dan D dalam Tabel 1 tentang normalitas volume gas di atas terbaca angka $\mathrm{A}$ : 1.104, B : 1.012, C : 1.229, dan D : 1.235 dengan probabilitas diatas 0,05 maka 
keempat variabel tersebut terdistribusi normal. Akan tetapi perolehan nilai sinifikasi dapat diurutkan terbaik sebagai berikut yaitu terbaik pertama pada produk gas B 0.258, kedua A 0.174, ketiga C 0.097, dan keempat D 0.095.

Perbandingan data produksi gas dengan distribusi normal ditunjukkan pada $\mathrm{B}$ dan $\mathrm{A}$, akan tetapi reaktor mana yang memiliki kuantitas dan kualitas terbaik akan dilanjutkan dengan analisis fakor bertujuan untuk mengidentifikasi struktur suatu data matriks dan menganalisis struktur saling hubungan (korelasi) antar sejumlah besar variabel.

Dengan cara meringkas informasi yang ada dalam variabel asli menjadi set dimensi baru atau variete (faktor).

Tabel 2.

KMO And Bartlett's Test Ke-3

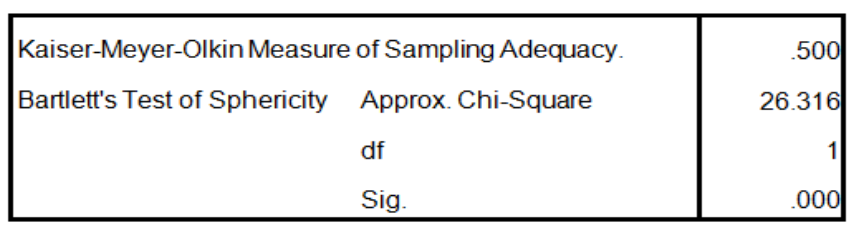

Sumber : Pengolahan Data, 2014

Hasil KMO pada Tabel 2 merupakan analisis ketiga dan yang terakhir, karena telah mendapatkan nilai KMO 0,5. Akan tetapi jika dirunut nilai KMO pertama yaitu 0,467 dan harus mengeluarkan data $\mathrm{D}$ karena memiliki angka anti image matriks terendah yaitu 0,397, kemudian dilanjutkan analisis kedua mendapatkan angka KMO 0,480 dan juga harus mengeluarkan data lagi yaitu data $\mathrm{C}$ karena memiliki angka anti image terendah yaitu 0,470. Dan sekarang analisis ketiga telah memenuhi syarat yaitu diatas 0,50 .

Bartlett's test of sphericity juga signifikan pada 0,05 . jadi dapat disimpulkan bahwa analisis faktor dapat diteruskan.

Tabel 3.

Total Variance Explainned

\begin{tabular}{|l|r|r|r|r|r|r|}
\hline \multirow{2}{*}{$\begin{array}{l}\text { Compo } \\
\text { nent }\end{array}$} & \multicolumn{3}{|c|}{ Initial Eigenvalues } & \multicolumn{3}{|c|}{ Extraction Sums of Squared Loadings } \\
\cline { 2 - 7 } & \multicolumn{1}{|c|}{ Total } & \% of Variance & Cumulative \% & \multicolumn{1}{c|}{ Total } & \% of Variance & Cumulative \% \\
\hline 1 & 1.724 & 86.177 & 86.177 & 1.724 & 86.177 & 86.177 \\
2 & .276 & 13.823 & 100.000 & & & \\
\hline
\end{tabular}

Extraction Method: Principal Component Analysis.

Sumber : Pengolahan Data, 2014

Dari Tabel 3 kedua variabel yang di analisis ternyata hasil ekstraksi komputer menjadi dua faktor (nilai eigen value $>1$ menjadi faktor).
Faktor 1 mampu menjelaskan $86,17 \%$ variasi sedangkan faktor ke-2 hanya $13,82 \%$ (kedua faktor mampu menjelaskan $100 \%$ variasi). 
Tabel 4.

Component Matriks ${ }^{\mathrm{a}}$

\begin{tabular}{l|l|}
\hline & \multicolumn{1}{|c|}{ Component } \\
\cline { 2 - 2 } & \multicolumn{1}{|c|}{928} \\
\hline Produk Gas A & 928 \\
Produk Gas B & \\
Extraction Method: Principal \\
Component Analysis. \\
a. 1 components extracted.
\end{tabular}

Sumber : Pengolahan Data, 2014

Tabel 5.

Descriptive statistics ke-3

\begin{tabular}{|l|c|r|r|}
\hline & Mean & Std. Deviation & Analysis N \\
\hline Produk GasA & 19.6289 & 6.96667 & 30 \\
Produk Gas B & 19.8632 & 7.39866 & 38 \\
\hline
\end{tabular}

Sumber : Pengolahan Data, 2014

Dengan melihat componen matrix dan descriptive statistics dua variabel Tabel 4 dan Tabel 5, sudah dapat mengelompok dengan loading factor sama yaitu 0.928 dan mean rata-rata 19.6 atau $0,56 \mathrm{~L} / \mathrm{Kg} /$ hari, maka kedua variabel dapat dijadikan strategi semua, maka penambahan cairan slurry 0,75 sampai dengan 1 liter ke dalam reaktor penelitian akan memberikan hasil yang sama. Percobaan pengolahan kotoran sapi percobaan pengolahan kotoran sapi dengan teknologi biogas reaktor kecil berhasil dengan Formulasi 58\% Feses sapi brahman ditambah $27 \%$ air ditambah $15 \%$ stater, terolah selama 38 hari menghasilkan biogas rata-rata 0.56 liter/Kg/hari.

\section{KESIMPULAN DAN SARAN}

\section{Kesimpulan}

Dari hasil pembahasan yaitu gambaran keempat reaktor dengan grafik polinomial, kemudian grafik regresi linier, normalitas data dengan Statistik Kolmogorov-Smirnov, dan uji analisis faktor menyimpulkan bahwa keempat reaktor menghasilkan biogas dengan distribusi normal, dan dengan regresi yang mendekati satu. Keempat reaktor dari visual grafik dan uji analisis faktor hanya reaktor $\mathrm{B}$ dan $\mathrm{A}$ yang dapat digunakan sebagai acuan pengolahan kotoran sapi yang menghasilkan biogas optimal, dan volumenya 0,56 liter biogas setiap satu kilogram kotoran sapi dengan waktu pengolahan 38 hari.

\section{Saran}

Penghematan anggaran untuk pengadaan peralatan pengolahan biogas berbahan baku kotoran sapi sekala rumah tangga atau usaha mikro peternakan dengan reaktor kecil yang berasal dari temuan campuran air yang sedikit yaitu $15 \%$ dan waktu tinggal yang cepat yaitu 38 hari, maka cara pengolahan ini dapat digunakan sebagai acuan dalam perencanaan pengolahan kotoran sapi dengan teknologi mikro biogas.

\section{DAFTAR PUSTAKA}

Arifin, M., Aep S., dan Arifin S. 2011. Kajian Biogas Sebagai Sumber Pembangkit Tenaga Listrik Di Pesantren Saung Balong Al- 
Barokah, Majalengka, Jawa Barat. Journal of Mechatronics, Electrical Power, and Vehicular Technology, Vol 02(2) : 73-78.

Ghozali, I. 2001 Aplikasi Analisis Multivariate Dengan program SPSS. Semarang : Badan Penerbit Universitas Diponegoro.

Mara, I. M. dan Ida Bagus Alit. 2011. Analisa Kualitas dan Kuantitas Biogas dari Kotoran Ternak. Jurnal, Vol 1(2) edisi Juli 2011.

Munawar, D. 2013. Memahami Pengertian dan Kebijakan Subsidi dalam APBN, Widyaiswara Utama BDK Cimahi. http://www.bppk.depkeu.go.id/bdk /cimahi/ attachments/299_Memahami\%20S ubsidi.pdf, diakses 14 maret 2014.

Prayitno, H. T. 2014. Strategi Pemanfaatan Kotoran Sapi. Jurnal litbang, X(1) : 43-51.

Sasongko, W. 2010. Produksi Biogas Dari Biomassa Kotoran Sapi Dalam Biodigester Fix Dome Dengan Pengenceran Dan Penambahan Agitasi. Tesis. Universitas Negeri Sebelas Maret : Surakarta.

Wahyudi, J. 2013. Strategi Pengembangan Biogas Pada Peternakan Sapi Perah. Jurnal litbang, IX(2) : 121-127.
Wati, L, Yuni A. dan Dezi H. 2014. Pengaruh Volume Cairan Rumen Sapi Terhadap Bermacam Feses Dalam Menghasilkan Biogas. Eksakta, Vol.1 : 20-28.

Widodo, T. W. dkk. 2006. Rekayasa Dan Pengujian Reaktor Biogas Skala Kelompok Tani Ternak. Jurnal Enginering Pertanian, Vol IV (1).

Windyasmara, L., Ambar P., dan Lies M. Y. 2012. Pengaruh Jenis Kotoran Ternak Sebagai Substrat Dengan Penambahan Serasah Daun Jati (Tectona Grandis) Terhadap Karakteristik Biogas Pada Proses Fermentasi. Buletin Peternakan $U G M$, Vol.36(1) : 40-47.

\section{BIODATA PENULIS}

Hermain Teguh Prayitno, lahir 11 April 1970 di kota Rembang Jawa Tengah. Magister Ilmu Lingkungan dari Universitas Diponegoro (UNDIP) Semarang tahun 2008. Saat ini bekerja sebagai peneliti pertama di Kantor Penelitian dan Pengembangan Kabupaten Pati. 